\begin{tabular}{ccc:c}
\hline Repo & KEGG ALS & Other & Row total \\
\hline DE & 9 & 1585 & 1594 \\
Non-DE & 13 & 6069 & 6082 \\
\hline Column total & 22 & 7654 & 7676 \\
\hline
\end{tabular}

\title{
Fisher's exact test
}

$p$-value $<0.0312$

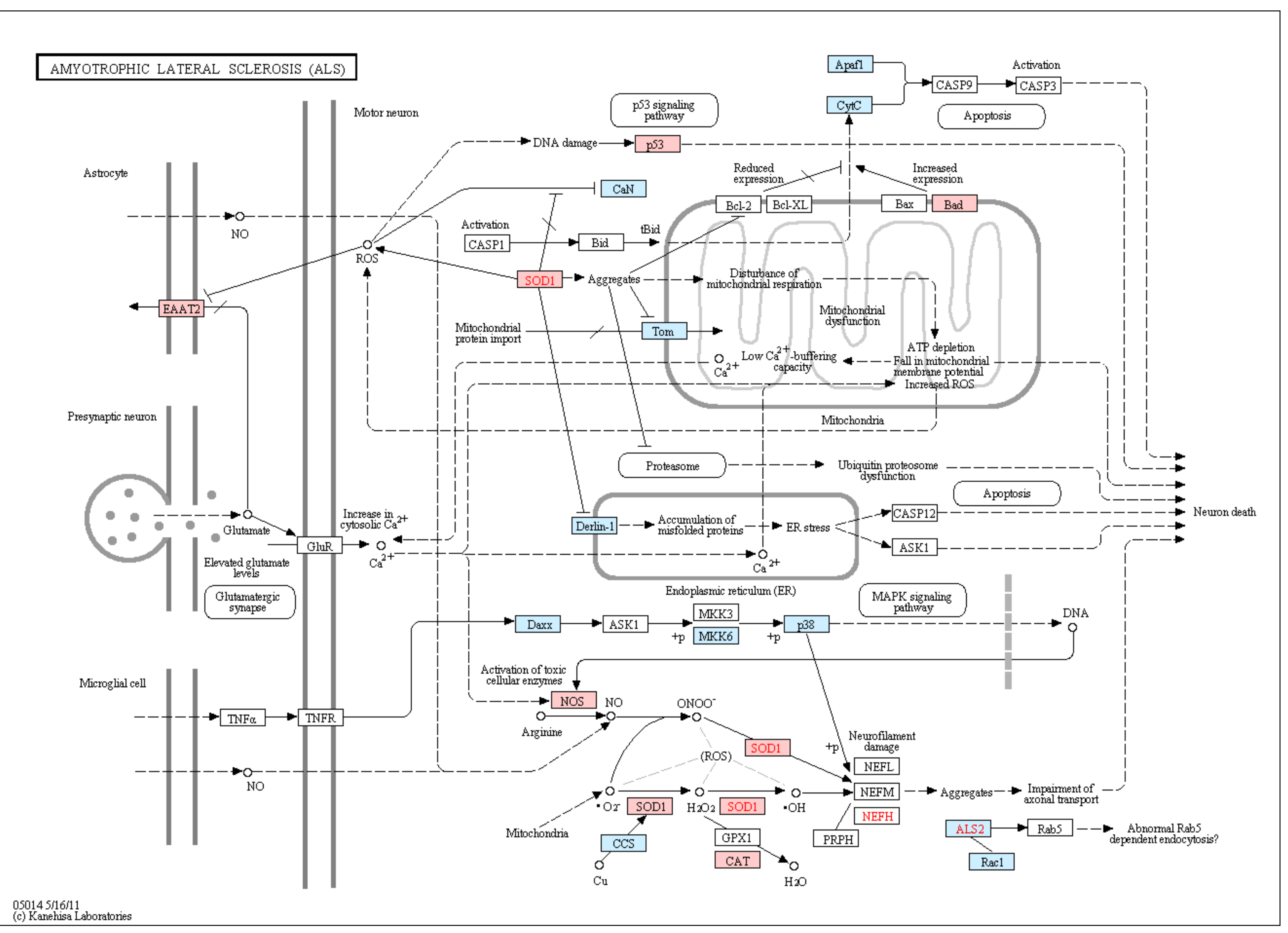

